\title{
DESCRIPTION OF A NEW SPECIES OF SPIDER OF THE GENUS CASTIANEIRA KEYSERLING (ARANEAE: CLUBIONIDAE) FROM MADHYA PRADESH
}

\author{
Pawan Gajbe \\ Central Regional Station, Zoological Survey of India, 424, New Adarsh Colony, Kamla Nehru Nagar, Jabalpur, Madhya Pradesh 482002, \\ India.Email:pugajbe@yahoo.com
}

\begin{abstract}
A new species of spider belonging to the genus Castianeira Keyserling under family Clubionidae is described from Jabalpur District in the state of Madhya Pradesh.
\end{abstract}

Keywords

Araneae, Castianeira adhartali sp. nov., Clubionidae, Madhya Pradesh, spider,

\section{Introduction}

Keyserling established the genus Castianeira in 1879. Eight species of this genus are known from India. Simon (1897) first recorded this genus from India by describing the species Castianeira zetes. Gravely (1931) gave an account of three species, Castianeira albopicta, C.flavipes and C. himalayensis, while Reimoser (1934) described one species, Castianeira quadrimaculata. Patel and Patel (1973) described the species Castianeira tinae, Tikader (1981) described Castianeira indica and Biswas (1984) described Castianeira bengalensis.

Jabalpur District (c. $23^{\circ} 10^{\prime} \mathrm{N}, 79^{0} 59^{\prime} \mathrm{E}$ ) lies in the eastern half of Madhya Pradesh. While examining some spiders collected from different areas of Jabalpur district, the author came across a new species of Castianeira Keyserling, which has been described herein. The type specimens have been deposited with the National Zoological Collection, Zoological Survey of India, Kolkata.

\section{Family Clubionidae}

1991. Clubionidae: Majumder \& Tikader, Rec. zool. Surv. India Occ. Pap. 102: 16.

Type genus

Clubiona Latreille, 1804

Distribution

All tropical parts of the world.

\section{Diagnosis}

Cephalothorax longer than wide, ovoid or elongated in shape. Dorsal groove usually distinct, short, shallow, sometimes located on posterior declivity. Eyes eight, homogeneous, arranged in two rows. Chelicerae rather long, outer margin with two to seven small teeth, inner margin with two to four small teeth. Maxillae usually longer than wide. Legs prograde, long and rather stout, tibia and metatarsi provided with long spines on ventral surface, tarsi with two claws. Abdomen is elongate, with variable ornamentation, dorsal scutum also present. Anterior spinnerets close together, not more heavily sclerotized than other spinnerets. These spiders are generally known as sac spiders since they construct silken tubular sac. Some of these are found on the ground among clumps of grass and under stones.

\section{Genus Castianeira Keyserling, 1879}

1879. Castianeira Keyserling, Ver. Zool.-bot. Ge. Wie. 29: 334. 1991. Castianeira: Majumder \& Tikader, Rec. Zool. Surv. India Occ. Pap. 102: 130.

\section{Type species \\ Castianeira rubicunda Keyserling, 1879}

\section{Distribution}

Africa, Asia, Malaysia, America, Canada, and India.

\section{Diagnosis}

Cephalothorax elongated, ovoid, with prominent cephalic shield 


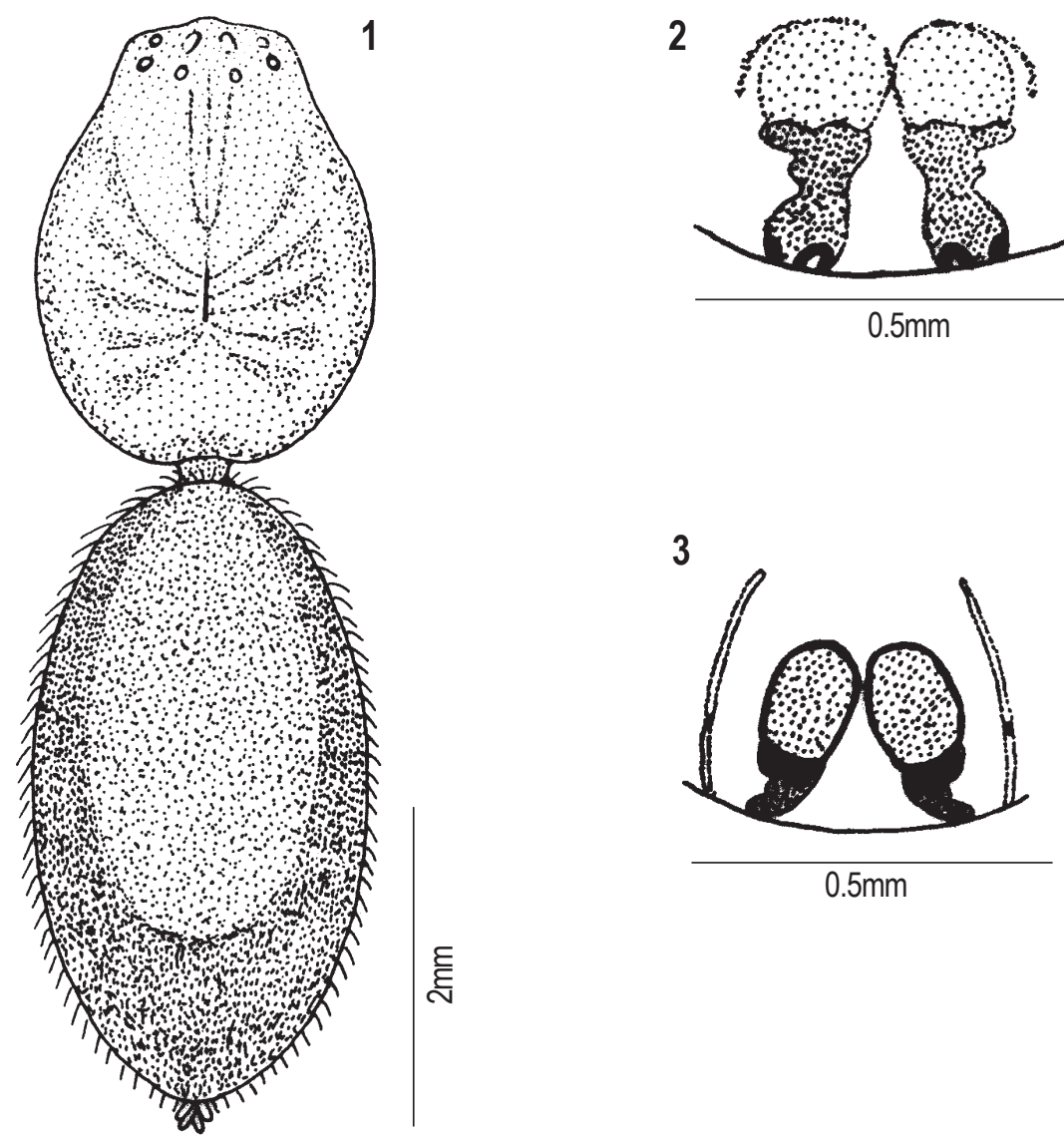

Figures 1-4. Castianeira adhartali sp. nov. 1. Dorsal view of female, legs omitted; 2. Epigyne; 3. Internal genitalia; 4. Left male palp, ventral view.

that is usually dark brown in colour, provided with median fovea, short sparse scale-like recumbent setae and with few longer setae in front of carapace. Eyes arranged in two rows, the anterior row slightly recurved and the posterior row distinctly procurved. Chelicera moderately long and stout with rarely 3 teeth on retromargin. Maxilla not constricted at the middle, more or less convex on its outer side. Legs rather long and slender, orange to dark brown to black in colour. Abdomen elongated, ovoid, often with transverse band.

\section{Castianeira adhartali sp. nov.}

(Figs. 1-4)

\section{Type specimens}

Holotype: Female, 5.x.1997, Adhartal, Jabalpur District, Madhya Pradesh, India, coll. Pawan Gajbe, ZSI Kolkata.

Allotype: Male, 5.x.1997, Adhartal, Jabalpur District, Madhya Pradesh, India, coll. Pawan Gajbe, ZSI Kolkata.

\section{Etymology}

The specific name refers to the type locality Adhartal, which is a large water tank in the northern part of Jabalpur City.

\section{Diagnosis}

General features: Cephalothorax and abdomen dark brown, legs light brown. Total length $7.3 \mathrm{~mm}$. Carapace $2.9 \mathrm{~mm}$. long, $2.7 \mathrm{~mm}$. wide; abdomen $4.2 \mathrm{~mm}$. long, $2.2 \mathrm{~mm}$. wide. 
Cephalothorax: Longer than wide, narrowing in front, clothed with fine pubescence, few hair in the cephalic region, thoracic region provided with a conspicuous fovea from which faint lines radiate toward the sides. Eyes pearly white, in two rows, anterior row slightly recurved, posterior row procurved, as in fig. 1. Anterior median eyes larger than others, lateral eyes nearly contiguous. Sternum heart-shaped, pointed behind, dark brown with three blackish spots laterally. Labium longer than wide with basal excavation prominent. Maxillae with pale distal margin and provided with distinct scopulae. Chelicerae strong, dark brown, fangs long. Legs long and stout, clothed with hair and spines. Male resembling female in general appearance but slightly larger in size. Male palp clothed with hair, basal portion of tarsus with few long hair, copulatory organ swollen, covering just a little over half the portion of tarsus, paracymbium short, as in fig. 4.

Abdomen: Longer than wide, elliptical, clothed with fine hair, dorsum with dark brown oval scutum, dorso-laterally and posteriorly blackish with numerous greyish dots, as in fig. 1 . Ventral side lighter than dorsal. Epigyne consisting of a sclerotised plate with the margins of spermathecae visible on it, as in fig. 2. Internal genitalia consisting of a pair of dumb-bell shaped spermathecae, as in fig. 3 .

\section{Remarks}

Castianeira adhartali sp. nov. resembles Castianeira indica Tikader but can be distinguished from it as follows:

1. Cephalothorax and abdomen dark brown, legs light brown but in $C$. indica, cephalothorax dark brown, abdomen brown and legs reddish-brown.

2. Sternum laterally provided with three blackish spots but such spots absent in $C$. indica.

3. Dorsum of abdomen with dark brown oval scutum, which is shorter in $C$. indica.

4. Lateral and posterior region of abdomen blackish with numerous greyish dots but this region is lighter in colour in $C$. indica.

5. Epigyne with a pair of dumb-bell shaped markings whose basal part is thicker than those in C. indica.

6. Male palp with copulatory organ smaller than in $C$. indica.

\section{Habitat}

The specimens were collected from under a stone in an undisturbed barren ground littered with stones and with a few clumps of Lantana camara bushes.

\section{Acknowledgements}

Thanks are due to Dr. J.R.B. Alfred, Director, Zoological Survey of India, Kolkata, and Dr. K. Chandra, Officer-in-charge, Zoological Survey of India, Central Regional Station, Jabalpur, for providing facilities for carrying out the research study.

\section{References}

Biswas, B.K. (1984). Description of six new species of spiders of the families Clubionidae, Gnaphosidae and Salticidae from India. Bulletin of the Zoological Survey of India 6(1-3): 119-127.

Gravely, F.H. (1931). Some Indian spiders of the families Ctenidae, Sparassidae, Solenopidae and Clubionidae. Records of the Indian Museum 33(3): 211-282.

Keyserling, E. (1879). Neue spinnen aus America. Verh Zoologie-bot Ges Wien 29: 293-349.

Majumder, S.C. and B.K. Tikader (1991). Studies on some spiders of the family Clubionidae from India. Records of the Zoological Survey of India, Occasional Paper No. 102: 1-175.

Patel, B.H. and H.K. Patel (1973). On some new species of spiders of family Clubionidae (Araneae: Arachnida) with a record of genus Castianeira Keyserling from Gujarat, India. Proceedings of the Indian Academy of Science 78(1): 1-9.

Reimoser, E. (1934). Araneae aus Süd-Indien. Rev Suisse Zoologie 41: 465-511.

Simon, E. (1897). Arachides recueillis par M.M. Maindron à Kurrachee et à Matheran (près Bombay) en 1896. Bulletin Museum Historie Naturae, Paris: 289-297.

Tikader, B.K. (1981). Studies on spiders of the genus Castianeira Keyserling (Family Clubionidae) from India. Bulletin of the Zoological Survey of India 4(3): 257-265. 